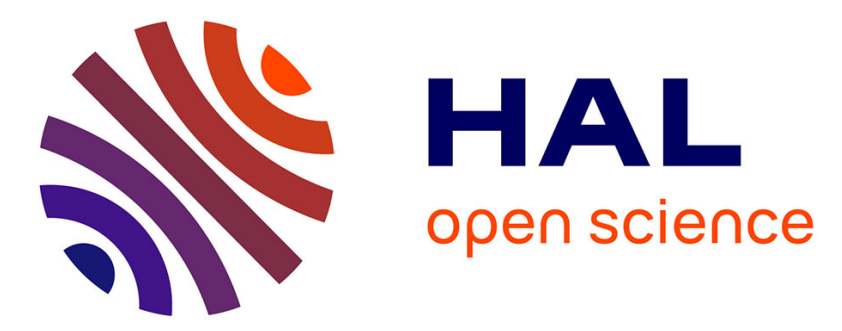

\title{
TDMQ20, a Specific Copper Chelator, Reduces Memory Impairments in Alzheimer's Disease Mouse Models
} Jie Zhao, Qihui Shi, Hongda Tian, Youzhi Li, Yan Liu, Zhen Xu, Anne Robert, Qiong Liu, B. Meunier

\section{- To cite this version:}

Jie Zhao, Qihui Shi, Hongda Tian, Youzhi Li, Yan Liu, et al.. TDMQ20, a Specific Copper Chelator, Reduces Memory Impairments in Alzheimer's Disease Mouse Models. ACS Chemical Neuroscience, 2021, 12 (1), pp.140-149. 10.1021/acschemneuro.0c00621 . hal-03079460

\section{HAL Id: hal-03079460 https://hal.science/hal-03079460}

Submitted on 17 Dec 2020

HAL is a multi-disciplinary open access archive for the deposit and dissemination of scientific research documents, whether they are published or not. The documents may come from teaching and research institutions in France or abroad, or from public or private research centers.
L'archive ouverte pluridisciplinaire HAL, est destinée au dépôt et à la diffusion de documents scientifiques de niveau recherche, publiés ou non, émanant des établissements d'enseignement et de recherche français ou étrangers, des laboratoires publics ou privés. 
2 TDMQ20, a specific copper chelator, reduces memory impairments in ADmouse models

Jie Zhao, Qihui Shi, Hongda Tian, Youzhi Li, Yan Liu, Zhen Xu, Anne Robert,* Qiong Liu,* Bernard Meunier*

\section{ABSTRACT}

Beside targeting amyloid or tau metabolisms, regulation of redox metal ions is a recognized therapeutic target for Alzheimer's disease (AD). Based on the bioinorganic chemistry of copper, we designed specific chelators of copper(II) (TDMQs) in sight to regulate copper homeostasis in the brain, and to inhibit the deleterious oxidative stress catalyzed by copper-amyloid complexes. An oral treatment by TDMQ20 was able to fully reverse the cognitive and behavioral impairment in three different murine models, two non-transgenic models mimicking the early stage of $\mathrm{AD}$, and a transgenic representing a more advanced stage of AD. To our knowledge, such comparative study using the same molecule has never been performed.

Regular C57 BL/6J mice received a single injection of human $\mathrm{Cu}-\mathrm{A} \beta_{1-42}$ in the lateral ventricles (icv- $\mathrm{CuA} \beta$ ) or in the hippocampus (hippo-CuA $\beta$ ). In both cases, mice developed a cognitive impairment similar to that of transgenic 5XFAD mice. Oral administration of TDMQ20 to icv$\mathrm{CuA} \beta$ or hippo- $\mathrm{CuA} \beta$ mice within a 16-days period resulted in a significant improvement of the cognitive status. The 3-months treatment of transgenic 5XFAD mice with TDMQ20 also resulted in behavioral improvements. The consistent positive pharmacological results obtained using these different AD models correlate well with previously obtained physico-chemical data of TDMQ20. The short-term novel object recognition (NOR) test was found particularly relevant to evaluate the rescue of declarative memory impairment. TDMQ20 was also able to reduce the oxidative stress in the mouse cortex. Due to its reliability and facile use, the hippo- $\mathrm{CuA} \beta$ model can be considered as a robust non-transgenic model to evaluate the activity of potential drugs on the early stages of memory deficits.

\section{KEYWORDS}

Alzheimer's disease / copper / chelator / memory / mouse models / hippocampus 


\section{INTRODUCTION}

Alzheimer's disease (AD) affects millions of people worldwide, and the incidence of this agerelated disease is increasing due to the increase of life expectancy in many countries. ${ }^{1,2}$ AD being mainly characterized by the formation of senile plaques of $\beta$-amyloid peptides and by neurofibrillary tangles due to the hyperphosphorylation of the tau protein, these phenomena have been considered as targets for the design of therapeutic agents.

Since memantine in 2003, no new drug has been approved, except sodium oligomannate (GV971), recently approved by the National Medical Products Administration of China. ${ }^{3}$ Between 2003 and 2019, $100 \%$ of drug-candidates failed in clinical trials. ${ }^{4}$ The quasi-exclusive use of transgenic mice to select drug-candidates for a disease which has no genetic origin for sporadic cases, might be questioned. Predictive and easy to handle mouse AD models are needed. In an attempt of diversification, we developed a non-transgenic mice model for the evaluation of the chelator PA1637. ${ }^{5}$ In this model, an episodic memory deficit was generated by a single intracerebroventricular (icv) injection in the brain of normal mice, of low molecular weight $A \beta_{1 \text { - }}$ 42 oligomers without copper. Despite controversies on the role of soluble amyloids, ${ }^{6}$ they are still considered as toxic agents contributing to synaptic alteration, abnormal tau phosphorylation, glial activation and neuronal loss in vivo. ${ }^{7}$ More recently, the key role of $A \beta$ oligomers to trigger activation of the glycogen synthase kinase $3 \beta$ (GSK $3 \beta$ ), responsible for tau hyperphosphorylation, has been demonstrated. ${ }^{8}$

Despite the capacity of PA1637 to extract copper from copper-amyloid in vitro, and to inhibit the catalytic production of $\mathrm{H}_{2} \mathrm{O}_{2}$ by $\mathrm{Cu}(\mathrm{II})$-amyloid ${ }^{9,10}$ its development has been stopped due to its rather low bioavailability. Consequently, we designed a new series of specific chelators of $\mathrm{Cu}(\mathrm{II})$ named TDMQ, based on a 8 -aminoquinoline skeleton with a chelating side-chain at $\mathrm{C} 2$ (Figure 1). Such tetradentate ligands have the required structure to discriminate between copper and zinc. ${ }^{11-15}$ Two 8-hydroxyquinolines, clioquinol (CQ) and PBT2, failed in clinical trials to improve cognition and reduce amyloid plaques. ${ }^{16,17}$ This failure might be explained by their lack of specificity for copper chelation, ${ }^{18,19}$ and their inability to inhibit the production of reactive oxygen species (ROS) generated by the Cu-amyloids. ${ }^{15,20}$ TDMQ ligands are able to extract copper(II) from $\mathrm{Cu}$-amyloids, without disturbing the activities of $\mathrm{Cu}, \mathrm{Zn}-\mathrm{SOD}$, tyrosinase or vitamin $\mathrm{B}_{12 .}{ }^{14}$ TDMQ20 has been selected as lead molecule for evaluation as anti-AD drug- 
a second chelator, differs from TDMQ20 by having a $\mathrm{CF}_{3}$ substituent at position 6 instead of $\mathrm{Cl}$ at $\mathrm{C} 5$ and $\mathrm{C} 7 .{ }^{13}$

Bis(8-amino)quinolines

TDMQ20, $\mathrm{R}=5,7-\mathrm{Cl}_{2}$
TDMQ22, $\mathrm{R}=6-\mathrm{CF}_{3}$

$R$<smiles>CN(C)CCNCCc1ccc2cc([Tl])cc(N)c2n1</smiles>

X-Ray diffraction structure of Cu"IDMQ20

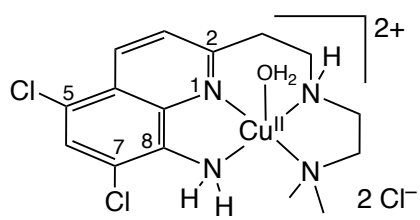

Mono(8-hydroxy)quinolines

Clioquinol (CQ)

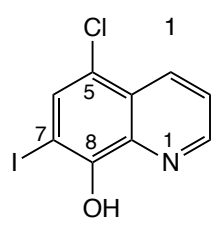

Figure 1. Structure of the chelators TDMQ20, TDMQ22, clioquinol (CQ) and PBT2, and structure of the copper(II) complex of TDMQ20, for its X-ray structure data, see Reference 11.

The deregulation of copper in AD brain and the associated memory deficits have been created by injection of the copper complex of amyloid $A \beta_{1-42}$ in the lateral ventricles (icv-CuA $\beta$ model) or hippocampus (hippo-CuA $\beta$ model) of regular mice. The third model was the transgenic mouse 5XFAD model. Data obtained with these three murine models indicated that the oral administration of TDMQ20 was able to inhibit memory deficits.

\section{RESULTS AND DISCUSSION}

\subsection{Mouse AD models, and drug treatment.}

In two non-transgenic mouse models, the cognitive deficit was created by injection of human $\mathrm{Cu}^{\mathrm{II}}$ $\mathrm{A} \beta_{1-42}$ complex either in the lateral ventricles (icv-CuA $\beta$ model) or in the hippocampus (hippo$\mathrm{CuA} \beta$ model) of regular young C57BL/6J mice (two months of age), at D0. The icv-CuA $\beta$ model of $\mathrm{AD}$ is similar to the icv injection of $\mathrm{A} \beta_{1-42}$ oligomers used to evaluate the tetradentate PA1637 chelator. ${ }^{5}$ In the second non-transgenic model, hippo- $\mathrm{CuA} \beta$, the $\mathrm{Cu}-\mathrm{A} \beta_{1-42}$ solution was injected in the hippocampus. This region of the brain is involved in declarative memory and learning as well as in spatial memory, and is particularly vulnerable in the early stages of AD. ${ }^{21,22}$ Atrophy of hippocampus is strongly correlated with cognitive decline. ${ }^{23}$ This non-transgenic hippo-CuA $\beta$ model can therefore contribute to mimic the early stages of $\mathrm{AD}$.

In these non-transgenic $\mathrm{AD}$ mice, the drug treatment consisted of oral gavage with TDMQ20, TDMQ22 or CQ used as comparator, 8 times between D4 and D20 (each dose was $10 \mathrm{mg} \mathrm{kg}^{-1}$ ). We also evaluated TDMQ20 on the transgenic 5XFAD transgenic mouse model (C57BL6 genetic background), that expressed human APP and PSEN1 transgenes with a total of five AD- 
linked mutations: the Swedish (K670N/M671L), Florida (I716V) and London (V717I) mutations in APP (the precursor of amyloids) and the two mutations in PSEN1 (M146L and L286V) (PSEN1 is the gene coding for presenilin-1, a constituent of $\gamma$-secretase). This model recapitulates several AD-related aspects of the disease, ${ }^{24,25}$ with early formation of amyloid plaques and gliosis at two months. Cognitive and motor deficits start at about 6 months, and develop with age in parallel with neuron degeneration in multiple brain regions. ${ }^{26,27}$

For 5XFAD mice, the drug treatment was carried out once every two days, from 2 to 5 months of age, and consisted of oral gavage with TDMQ20, or CQ used as comparator, (45 times, each drug dose: $10 \mathrm{mg} \mathrm{kg}^{-1}$ ). The mouse cognitive status was evaluated using the standardized behavioral tests: novel object recognition (NOR), elevated plus maze test (EPM), open field test (OFT), and Y-maze test (YMT), at the end of the treatment (between D22 and D26 for the icv-

$111 \mathrm{CuA} \beta$ model and the hippo-CuA $\beta$ model), and between 5.2 and 5.6 months of age for the 5XFAD 112 mice.

\subsection{TDMQ20 inhibits of the cognitive impairment of AD mice.}

\section{2.2.1. Novel object recognition (NOR)}

116 The NOR test, based on the spontaneous propensity of rodents to explore new objects, allows the 117 evaluation of short-term- or long-term memory, ${ }^{28}$ assessing cognitive deficits in a wide range of 118 pathological conditions, in transgenic and non-transgenic murine models of AD. ${ }^{29}$ This assay is particularly relevant to $\mathrm{AD}$, and consequently for the evaluation of the efficacy of potential drugs since it is dependent on the integrity of the temporal regions affected in the early stages of AD.

The recognition index is calculated as the percentage of explorations of a novel object with respect to the total number of explorations for short-term memory or long-term memory $\left\{\left[\left(n_{Y} / n_{X+Y}\right) \times 100\right]\right.$ or $\left[\left(n_{Z} / n_{X+Z}\right) \times 100\right]$, respectively, where $n_{X}, n_{Y}, n_{Z}$ stand for the number of explorations of familiar object $\mathrm{X}$, novel object $\mathrm{Y}$ in short-term memory evaluation, or novel object $\mathrm{Z}$ in long-term memory evaluation, respectively $\}$. The recognition index is reported in Figure 2 for the icv-CuA $\beta$ (panel A), the hippo-CuA $\beta$ (panel B), and the 5XFAD (panel C) mouse models.

First of all, for short-term memory evaluation, the recognition index was significantly lower for the icv- $\mathrm{CuA} \beta$ mice or hippo- $\mathrm{CuA} \beta$ mice compared to the healthy controls (Figure 2, panel A or B, respectively), indicating that this test was relevant to discriminate between healthy and nontransgenic $\mathrm{AD}$ mice, a necessary condition to evaluate the activity of potential drugs on these models. Contrary, the difference of the recognition index was not statistically significant between 
5XFAD mice and their wild type littermates (panel C), consistent with bibliographic data indicating that, in transgenic models of $\mathrm{AD}$, the performance of mice in the NOR is age-dependent and deficits appear only after 6 months of age, ${ }^{29}$ or even later. ${ }^{30}$

This result suggests that icv-CuA $\beta$ - and hippo- $\mathrm{CuA} \beta$ mice are mimicking early cognitive impairment of $\mathrm{AD}$, whereas such damages are probably undetectable in young $5 \mathrm{XFAD}$ mice.
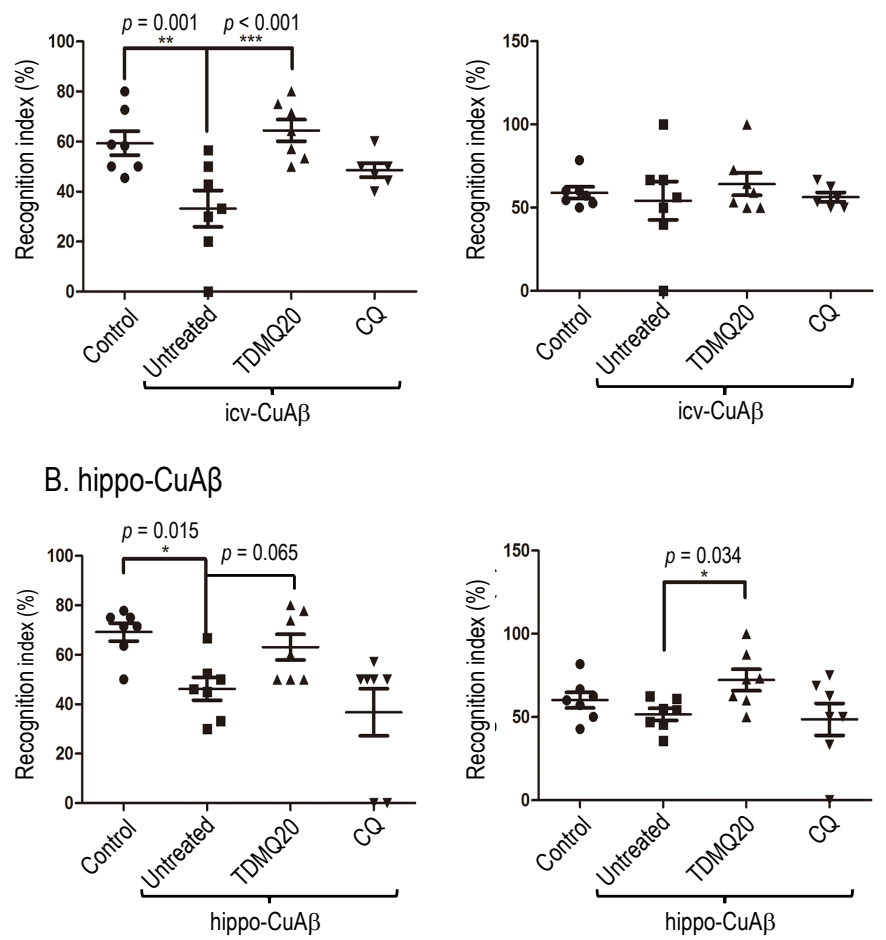

$$
\text { C. 5XFAD }
$$

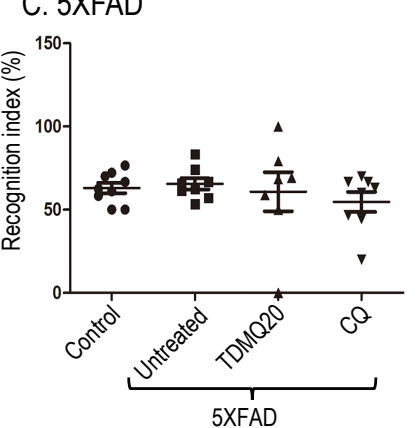

Figure 2. Declarative memory evaluated by the recognition index $\left[\left(n_{Y} / n_{X+Y}\right) \times 100\right]$ for short term memory or $\left[\left(\mathrm{n}_{\mathrm{Z}} / \mathrm{n}_{\mathrm{X}+\mathrm{Z}}\right) \times 100\right]$ for long-term memory in the NOR task in the icv-CuA $\beta$ (panel A) and the hippo-CuA $\beta$ (panel B) non-transgenic mouse models, and in the transgenic 5XFAD (panel C) model. $\mathrm{n}_{\mathrm{X}}, \mathrm{n}_{\mathrm{Y}}, \mathrm{n}_{\mathrm{Z}}$ stand for the number of explorations of familiar object $\mathrm{X}$, novel object $\mathrm{Y}$ in short-term memory evaluation, or novel object $\mathrm{Z}$ in long-term memory evaluation, respectively. In each case, the recognition index of AD mice which received no drug-treatment (untreated group) was compared to that of healthy mice (control group), and to the recognition index of AD mice treated with TDMQ20 or clioquinol $\left[8 \times 10 \mathrm{mg} \mathrm{kg}^{-1}\right.$ in 16 days (panels A and B), or $10 \mathrm{mg} \mathrm{kg}^{-1}$, one every two days during 3 months (panel $\mathrm{C}$ )]. In panels $\mathrm{A}$ or $\mathrm{B}$, the control/untreated groups were brain-injected with $\mathrm{CuA} \beta / \mathrm{PBS}$. In panel $\mathrm{C}$, the untreated and control groups were the transgenic 5XFAD mice and their non-transgenic littermates drug. For details, see SI. Each mark represents the result obtained with a single mouse; horizontal lines represent 
Revised ms ID cn-2020-00621j to ACS Chemical Neuroscience, December 3, 2020

mean values \pm SEM [panels A and B: $n=7$ (controls) or 6-7 (untreated- or treated AD mice); panel C: $n=9$ (controls) or 7-8 (untreated- or treated 5XFAD mice)]. ${ }^{* *} p<0.01,{ }^{*} p<0.05$ vs. the untreated AD group (ANOVA).

After a short oral treatment by TDMQ20 icv-CuA $\beta$ mice spent significantly more time exploring the novel object in the short-term memory test, compared to untreated AD mice. A similar trend was evidenced for hippo-CuA $\beta$ mice. In fact, the recognition index of treated mice was similar to the score of control mice. Then, TMDQ20 significantly reduced the cognitive injuries created by the intracerebral injection of the $\mathrm{Cu}-\mathrm{A} \beta_{1-42}$ complex. By comparison, $\mathrm{CQ}$ did not significantly improved the short-term memory of icv-CuA $\beta$ mice and hippo-CuA $\beta$ mice. Duplication of these experiments using icv- $\mathrm{CuA} \beta$ - and hippo- $\mathrm{CuA} \beta$ mice provided fully consistent results provided as Supporting Information (Figure S1). The ability of TDMQ22 to restore the short-term memory of icv-CuA $\beta$ mice was close to that of TDMQ20 (SI, Figure S1, panel A).

Contrary to the short-term memory, the long-term recognition index was not significantly impaired in icv-CuA $\beta$ - and hippo-CuA $\beta$ mice (panels $\mathrm{A}$ and $\mathrm{B}$, right). This result suggests that these models efficiently mimic the early stage of $\mathrm{AD}$, in which the short-term memory is the first to be impaired, while the long-term memory, including semantic and procedural memories are not yet significantly impacted. We should note that the development of efficient drugs requires the use of mouse models of the early stages of the disease, and not a model for the late stages, where cognitive and anatomic damages are irreversible.

\subsubsection{Y-maze test}

The Y-maze test is a measure of spatial working memory driven by the innate curiosity of rodents to explore previously unvisited areas. ${ }^{31}$ The spontaneous alternation of mice in the Y-maze has been validated as a hippocampal relevant spatial task. ${ }^{32,33}$ The spontaneous alternation ratios of hippo- $\mathrm{CuA} \beta$ - and 5XFAD mice in the Y-maze are reported in Figure 3, panels $\mathrm{A}$ and $\mathrm{B}$, respectively. The 5XFAD mice exhibit a tendency to reduced spontaneous alternation ratio compared with wild-type mice (Figure 3), consistent with previous reports indicating that alternation ratio was impaired after the age of 6 months. ${ }^{24,25}$ The oral treatment by TDMQ20 restored the alternation ratio of 5XFAD mice (panel B) up to the level of control mice, with nearly the same efficacy than CQ. A similar trend was obtained with hippo-CuA $\beta$ mice. Due to the result lack of statistical significance, we suggest that the spatial memory impairment is not yet established in these non-transgenic early AD mice. Therefore this test is poorly suitable to evaluate the cognitive impairment and the efficacy of drugs in 2-3 month old hippo-CuA $\beta$ mice. 
A. hippo-CuAß

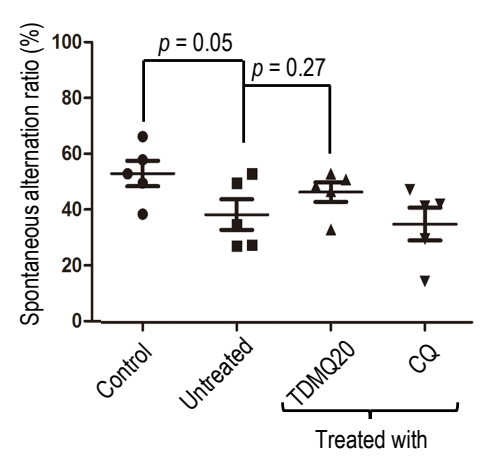

B. 5XFAD

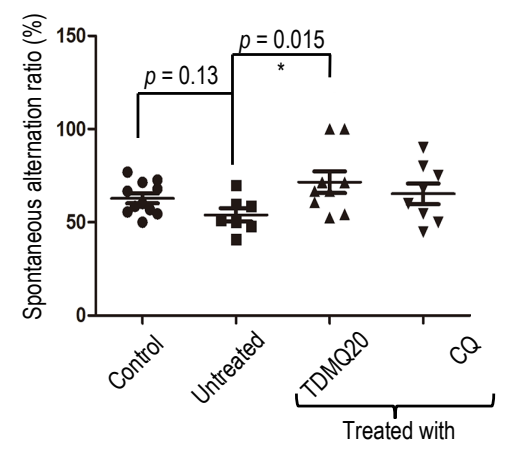

Figure 3. Spatial memory evaluated by the spontaneous alternation ratio in the in the Y-maze task for the hippo$\mathrm{CuA} \beta$ (panel A) non-transgenic mouse model, and the transgenic 5XFAD (panel B) model. In each case, the spontaneous alternation rate of $\mathrm{AD}$ mice which received no drug-treatment (untreated group) was compared to that of healthy mice (control group), and to the alternation ratio of AD mice which received TDMQ20 or clioquinol ( $\times$ $10 \mathrm{mg} \mathrm{kg}^{-1}$ in 16 days, panel $\mathrm{A}$, or $10 \mathrm{mg} \mathrm{kg}^{-1}$, one every two days during 3 months, panel $\mathrm{B}$ ). In panel $\mathrm{A}$, the control/untreated groups were brain-injected with $\mathrm{CuA} \beta$ in PBS. In panel B, the untreated and control groups were the transgenic 5XFAD mice and their non-transgenic littermates, respectively. All control and untreated mice received oral gavage with aqueous $\mathrm{NaCl} 0.9 \mathrm{w} / \mathrm{v}$ instead of drug. For details, see SI. Each mark represents the result obtained with a single mouse; horizontal lines represent mean values \pm SEM [(A): $n=5 ;(B): n=9$ (controls) or 7-8 (untreated- or treated 5XFAD mice]. $p$ values in the ANOVA are indicated.

\subsubsection{Open field test}

228 In the open-field assay, the unsupported rearings and travel distances of the hippo-CuA $\beta$ mice in the open-field were found significantly lower than that of age-matched controls, indicating that the locomotor deficit of hippo-CuA $\beta$ mice was well established (Figure 4A). Here also, the treatment by TDMQ20 for a short period of 16 days resulted in full rescue of the mouse abilities, with both rearings and travel distances similar to that of controls.

Conversely, the locomotor activity of 5XFAD mice was found rather close to that of the corresponding healthy mice, with no significant difference in the rearings between WT and 5XFAD mice (Figure 4B). This is consistent with the fact that the exploratory behavior and locomotor activity of 5XFAD mice were reported as being normal at least until 6 months, ${ }^{26,27}$ or 9-12 months old. ${ }^{25,30}$ However, in our hands, the grid crossings by 5XFAD animals was significantly higher than that of their WT littermates (Figure 4B), suggesting that, at 5.4 months, brain damage were already installed. In these conditions, the treatment by TDMQ20 significantly normalized the grid crossing by transgenic AD mice. 
A. hippo-CuA
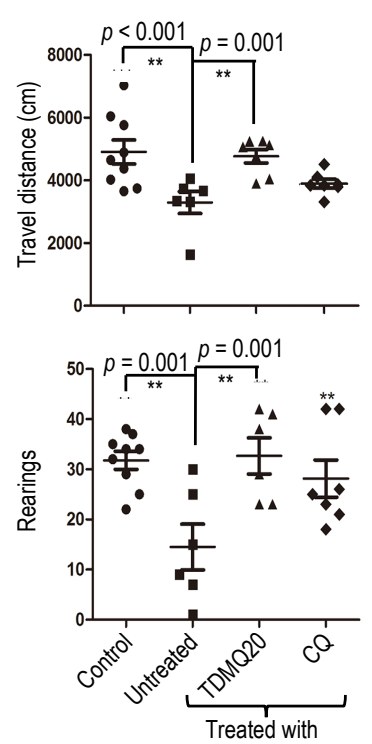

B. 5XFAD
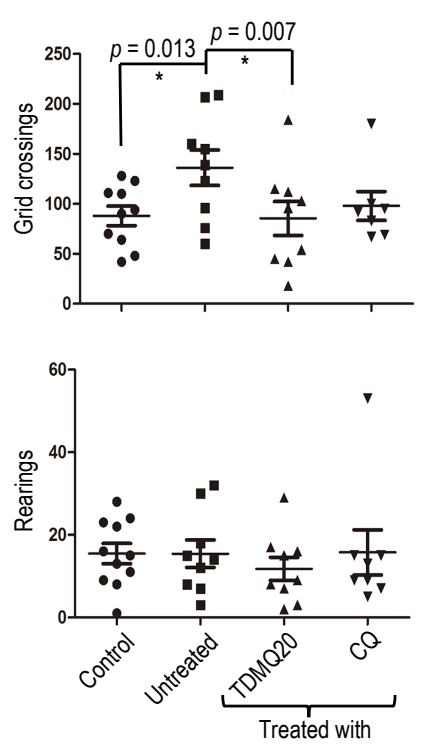

Figure 4. Locomotion ability evaluated by the crossings, travel distances, and rearings, in the open field test for the hippo- $\mathrm{CuA} \beta$ (panel A) non-transgenic mouse model, and the transgenic 5XFAD (panel B) model. In each case, the scores of AD mice which received no drug-treatment (untreated group) was compared to that of healthy mice (control group), and to the scores of AD mice which received TDMQ20 or clioquinol $\left(8 \times 10 \mathrm{mg} \mathrm{kg}^{-1} \mathrm{in} 16\right.$ days, panel A, or $10 \mathrm{mg} \mathrm{kg}^{-1}$, one every two days during 3 months, panel B). In panel A, the control/untreated groups were braininjected with $\mathrm{CuA} \beta$ in PBS. In panel B, the untreated and control groups were the transgenic 5XFAD mice and their non-transgenic littermates, respectively. All control and untreated mice received oral gavage with aqueous $\mathrm{NaCl} 0.9$ $\mathrm{w} / \mathrm{v}$ instead of drug. For details, see SI. Each mark represents the result obtained with a single mouse; horizontal lines represent mean values \pm SEM. [(A): $n=9$ (control), or 6-7 (untreated or treated hippo-CuA $\beta$ mice; $(B): n=10$ (control), or 7-9 (untreated or treated 5XFAD mice]. ${ }^{* *} p<0.001,{ }^{* *} p<0.01,{ }^{*} p<0.05$ vs. untreated AD mice (ANOVA).

\subsubsection{Elevated plus maze}

The elevated plus maze assay has been described for assessing anxiety response of rodents, and screening of drugs for treatment of anxiety-related disorders. ${ }^{34,35}$ The score of 5XFAD mice in the elevated plus maze is reported in Figure 5. 5XFAD mice exhibited an increased number of closed arm entries, and a decreased proportion of time spent in closed arms, compared to their WT littermates. Normally, mice tend to avoid the open arms, seeking protection in the closed arms. A decreased proportion of time spent in closed arms indicate a decreased anxiety of 5XFAD mice (Figure 5), that may correspond to dis-inhibitory tendencies seen in AD patients. ${ }^{25,26}$ Oral treatment of these mice with TDMQ20 fully reversed their behavior to to the score of WT, more efficiently than the CQ treatment did. 

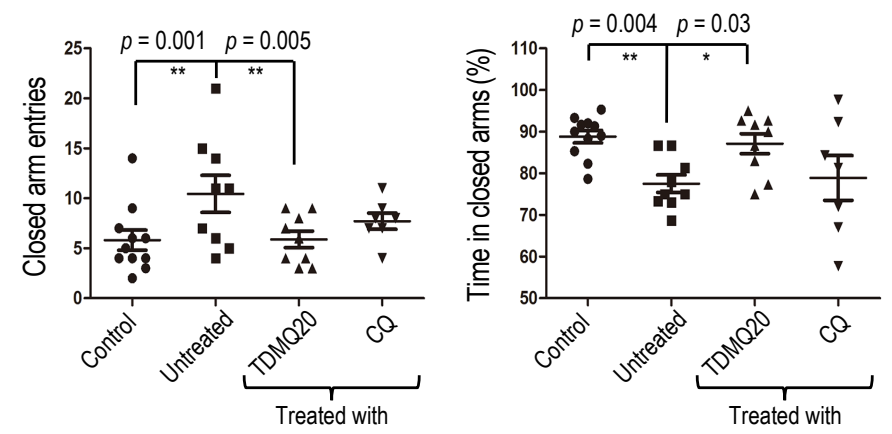

Figure 5. Anxiety evaluated by the closed arm entries and time spent in closed arms, in the elevated plus maze test for the transgenic 5XFAD model. The scores of AD mice which received no drug-treatment (untreated group) was compared to that of wild-type mice (control group), and to that of AD mice which received TDMQ20 or clioquinol (10 $\mathrm{mg} \mathrm{kg}^{-1}$, one dose every two days during 3 months). The untreated and control groups were the transgenic 5XFAD mice and their non-transgenic littermates, respectively. All control and untreated mice received oral gavage with aqueous $\mathrm{NaCl} 0.9 \mathrm{w} / \mathrm{v}$ instead of drug. For details, see SI. Each mark represents the result obtained with a single mouse; horizontal lines represent mean values \pm SEM. (controls: $n=9$; untrated- or treated 5XFAD mice: $n=7-8$ ). $* * * p<0.001, * * p<0.01, * p<0.05$ vs. the untreated 5XFAD mice (ANOVA).

As a summary of behavioral tests (Table 1), both 2.5-2.7 month hippo-CuA $\beta$ or icv-CuA $\beta$ mice exhibited significant deficits of short-term memory in the NOR assay. The score of the hippo-CuA $\beta$ mice was also impaired in the open-field assay, validating these non-transgenic models to evaluate the activity of potential drugs on the early stages of the memory deficits. The short oral treatment with TDMQ20 was efficient to fully restore the abilities of mice in these reference tests. The score of hippo-CuA $\beta$ mice in the Y-maze was less impaired than in transgenic 5XFAD mice, but nevertheless confirmed that TDMQ20 was able to reverse the ongoing impairment of the spatial memory on young mice affected by intracerebral injection of copperamyloids.

Conversely, the deficits of 5XFAD mice observed in the open field, Y-maze or elevated plus maze assays, are rather weak below 6 months of age. Cognitive deficits of these transgenic mice are reported to correlate well with an increasing burden of amyloid plaques in the cortex and hippocampus, axonal degeneration, spinal cord pathology and neuron loss in specific cortical layer, mimicking an advanced AD pathology. ${ }^{25}$ Similarly, in APP/PS-1 mouse model, the cognitive deficits in both recognition memory and spatial memory become apparent only at 1124 months of age, when the disease damages are definitively installed ${ }^{36}$ In these conditions, such transgenic models should be considered more relevant to describe advanced stages of $\mathrm{AD}$, but are probably not really adapted to evaluate drug-candidates that should be efficient on the early stages of the disease. 
Revised ms ID cn-2020-00621j to ACS Chemical Neuroscience, December 3, 2020

314 Table 1. Improvement of the scores of AD mice treated by TDMQ20, with respect to untreated AD controls.

315

316

317

318

319

320

321

322

323

324

325

326

327

328

329

330

331

332

333

334

335

336

337

338

339

340

341

342

343

344

345

346

347

AD mouse model

icv-CuA $\beta \quad$ hippo-CuA $\beta \quad$ XXFAD

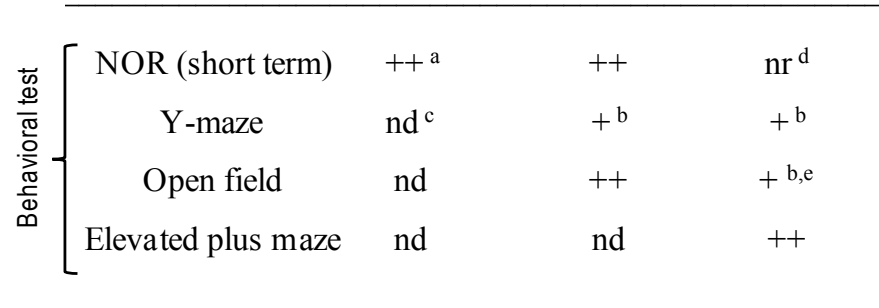

\section{Cortex}

oxidative MDA level $\quad+{ }^{b} \quad$ nd $\quad+b$

status

a ++ Means: Statistically significant with $p$-value $\leq 0.05$ (ANOVA); $b+$ Means: tendency, but with $p$-value $>0.05 ;{ }^{\mathrm{c}}$ Not determined; ${ }^{\mathrm{d}}$ Not relevant (no significant difference between WT controls and 5-month old 5XFAD mice; e Only for grid crossing.

\subsection{TDMQ20 inhibits cortex oxidative injuries}

The ability of TDMQ20 to rescue cognitive deficits is consistent with the capacity of this copper homeostasis regulator to reduce in vitro the formation of ROS. ${ }^{13,20}$ In fact, neuro-inflammation is considered a key factor of the loss of neurons and synapses in AD. ${ }^{30}$ The molecular origin of brain inflammation might be linked to the oxidative stress initiated by the reductive activation of dioxygen catalyzed by copper-amyloids. It is therefore relevant to evaluate the oxidative status of the mouse brains. For this purpose, the malondialdehyde (MDA) level is significant of the potential occurrence of peroxide induced lipid injuries. ${ }^{37}$

The level of MDA, measured by the thiobarbituric reactive species (TBARS) assay, in the cortex of icv-CuA $\beta$ - and 5XFAD mice is reported in Figure 6A and 6B, respectively.

$$
\text { A. Icv-CuA } \beta
$$

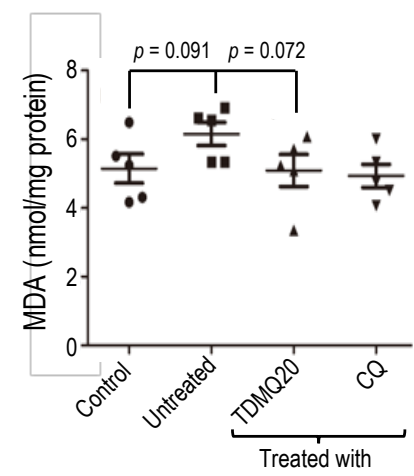

B. 5XFAD

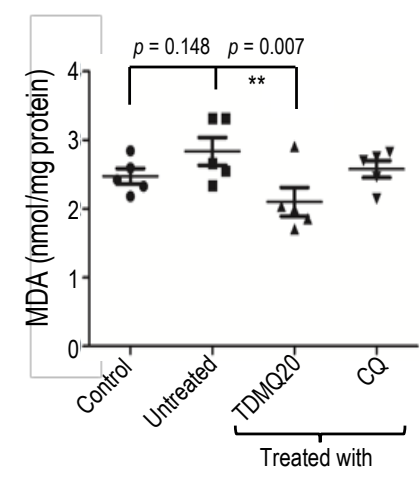

Figure 6. Effect of TMDQ20 on the level of malondialdehyde in the cortex of icv-CuA $\beta$ AD mice (A) and 5XFAD mice (B). (A): The control mice were brain-injected with PBS 1X/DMSO, 80/20, v/v; untreated mice were brain injected with $\mathrm{CuA} \beta$ in $1 \mathrm{X} / \mathrm{DMSO}, 80 / 20$, v/v. (B): The controls were WT C57BL/6J mice. All control and untreated 
Revised ms ID cn-2020-00621j to ACS Chemical Neuroscience, December 3, 2020

mice received oral gavage with aqueous $\mathrm{NaCl} 0.9 \mathrm{w} / \mathrm{v}$ instead of drug. Each mark represents the result obtained with a single mouse; horizontal lines represent mean values \pm SEM of $\mathrm{n}=5$ experiments. Relevant $p$ values are indicated (ANOVA).

The concentration of MDA in the cortex of AD mice, transgenic (5XFAD) or not (icv-CuA $\beta$ ), was slightly higher than that of the controls (Figure 6), supporting the involvement of an oxidative stress in these mice. In both cases, the treatment with TMDQ20 reduced the MDA level in the cortex until the level of control mice, indicating a normalization of the oxidative status in the cortex. This encouraging data is consistent with the ability of TDMQ20 to inhibit in vitro the production of ROS induced by $\mathrm{Cu}-\mathrm{A} \beta{ }^{13,15}$

\subsection{Preliminary safety and druggability studies of TDMQ20}

\subsubsection{Single dose}

In an acute toxicity assay in WT C57BL/6J mice, TDMQ20 was found completely safe after administration of an oral dose 150 or $200 \mathrm{mg} \mathrm{kg}^{-1}$, corresponding to 15-20 times the dose used to treat $\mathrm{AD}$ mice, with all mice surviving without any detectable deficit (Table 2). The drug exhibited some delayed toxicity by ip route at $150 \mathrm{mg} \mathrm{kg}^{-1}$ : two mice over 11 died at D3 and D15, respectively, indicating an $\mathrm{LD}_{50}$ value higher than $150 \mathrm{mg} \mathrm{kg}^{-1}$. By comparison, clioquinol was found significantly more toxic, with $\mathrm{LD}_{50}$ values close to $200 \mathrm{mg} \mathrm{kg}^{-1}$ and $150 \mathrm{mg} \mathrm{kg}^{-1}$, by oral and ip route, respectively (2/5 and 7/11 mice died on the day of drug administration).

Table 2. Preliminary toxicological evaluation of TMDQ20 compared to CQ on C57BL/6J mice, after a single oral or intraperitoneal (ip) dose.

\section{Survival of mice treated with a single dose of TDMQ20 or CQ}

\begin{tabular}{|c|c|c|c|c|}
\hline Drug & $\begin{array}{c}\text { Dose } \\
\left(\mathrm{mg} \mathrm{kg}^{-1}\right)\end{array}$ & $\begin{array}{l}\text { Administration } \\
\text { route }\end{array}$ & Survival & $\begin{array}{c}\text { Date } \\
\text { of death }\end{array}$ \\
\hline TDMQ20 & $\left\{\begin{array}{l}150 \\
200 \\
150\end{array}\right.$ & $\begin{array}{c}\text { oral } \\
\text { oral } \\
\text { ip }\end{array}$ & $\begin{array}{c}6 / 6 \\
5 / 5 \\
9 / 11\end{array}$ & $\begin{array}{c}- \\
- \\
\text { D3, D15 }\end{array}$ \\
\hline CQ & $\left\{\begin{array}{l}150 \\
200 \\
150\end{array}\right.$ & $\begin{array}{c}\text { oral } \\
\text { oral } \\
\text { ip }\end{array}$ & $\begin{array}{c}6 / 6 \\
3 / 5 \\
4 / 11\end{array}$ & $\begin{array}{c}- \\
\text { D1 } \\
\text { D1 }\end{array}$ \\
\hline
\end{tabular}

\subsubsection{Multiple doses}

The toxicity of TDMQ20 was then evaluated after on oral administration of $100 \mathrm{mg} \mathrm{kg}^{-1}$ every day to WT C57BL/6J mice. Two mice died at D8 and D9 (survival 8/10), ie. after administration of 10-11 times the total drug dose used in the AD treatment ( $80 \mathrm{mg} \mathrm{kg}^{-1}$ in total). The assay was 
then discontinued at D9. Mice $(\mathrm{n}=9)$ were then treated with TDMQ20 by oral route at $80 \mathrm{mg} \mathrm{kg}^{-}$ 1, 3 times a week during 2 weeks, corresponding to a total dose of $480 \mathrm{mg} \mathrm{kg}^{-1}$. In these conditions, with a schedule similar to that used for the evaluation of the pharmacological activity of TDMQ20 ( $80 \mathrm{mg} \mathrm{kg}^{-1}$ in total), all mice survived without any detectable sign of toxicity during the treatment, suggesting a safety index $\geq 8$. In addition, the treatment of 5XFAD mice clearly indicated that this drug-candidate was well tolerated upon long-term oral treatment (45 doses, $450 \mathrm{mg} \mathrm{kg}^{-1}$ in total), even in animals weakened by the disease.

The aspartate aminotransferase (AST), alanine aminotransferase (ALT), creatinine and urea were measured in the serum of 5XFAD mice, treated or not by TDMQ20 $\left(45 \times 10 \mathrm{mg} \mathrm{kg}^{-1}\right.$ in 3 months, total dose $=450 \mathrm{mg} \mathrm{kg}^{-1}$ ), at the end of the treatment period and compared to the levels found in the WT C57BL/6J controls. There was no significant difference between the levels obtained for the WT controls, the 5XFAD mice and the 5XFAD mice treated by TDMQ20, indicating the lack of any detectable damage on liver and kidneys upon long-term oral treatment with TDMQ20 in these conditions (45 doses, $450 \mathrm{mg} \mathrm{kg}^{-1}$ in total).

402

\subsubsection{Druggability}

In vitro preliminary metabolic studies indicate that the TDMQ20 significantly inhibits CYP 2D6, but not CYP 3A $(<20 \%)$ and 2C9 $(<5 \%)(\mathrm{SI})$. We have to remember that the drug prozac is also an inhibitor of CYP2D6. The measured $\mathrm{pKa}$ values indicate that, at physiological $\mathrm{pH}$, TDMQ20 should exist as a mixture of species, due to mono- and diprotonation of the side chain, ${ }^{15}$ like many CNS drugs containing protonable nitrogen sites. ${ }^{38}$ The calculated $\log \mathrm{P}$ value for TDMQ20 is $2.5,{ }^{39}$ and topological polar surface area (tPSA) is $53 \AA^{2},{ }^{39}$ in the range consistent for passive transport across the blood-brain barrier. ${ }^{38}$ The membrane crossing capacity has been confirmed by the Caco-2 data. In standard conditions at 10-5 M, A-B permeability was 8.4 with a recovery of $35 \%$ and B-A permeability was 10.1 with a recovery of $74 \%$. In addition, TDMQ20 was Ames negative on TA98, TA100, TA1535 and TA1537, even after microsomal activation (SI), indicating that this ligand was not mutagenic in bacteria. non-transgenic mouse models of the early stage of $\mathrm{AD}$ and in a transgenic model. With the icv-

$418 \mathrm{CuA} \beta$ and hippo- $\mathrm{CuA} \beta$ models, the short-term NOR test is specially robust to evaluate the 
impairment of the declarative memory in mice, making such models easy to select molecules that should be active on the early stages of AD.

The efficacy of TDMQ20 by oral administration of low doses on three different mouse AD models is an encouragement for further pharmacological evaluations of this specific copper chelator.

\section{METHODS}

426

\subsection{Materials.}

Human $\mathrm{A} \beta_{1-42}\left(\mathrm{CF}_{3} \mathrm{COO}^{-}\right.$as counter-ions) was obtained from Aladdin, China. According to a protocol adapted from Reference 40, $\mathrm{A} \beta_{1-42}(1 \mathrm{mg})$ was dissolved in 1,1,1,3,3,3hexafluoroisopropanol (HFIP, $1 \mathrm{~mL}$ ) and sonicated for 15 minutes. The solution was centrifugated at $12,000 \mathrm{rpm}$ for $15 \mathrm{~min}$. The concentration of the $A \beta_{1-42}$ solution was determined using Micro BCA Protein Assay kit from ThermoFisher Scientific ${ }^{\mathrm{TM}}$ (code 23235), working with BSA (bovine serum albumin) as a calibration protein. HFIP was then removed by lyophilization, and the solid $\mathrm{A} \beta_{1-42}$ was then stored at $-20{ }^{\circ} \mathrm{C}$ until used. The chelators TDMQ20 and TDMQ22 were synthesized as previously reported. ${ }^{12,13}$ Clioquinol (5-chloro-7-iodo-8-hydroxyquinoline, CQ), $\mathrm{CuCl}_{2}, \mathrm{DMSO}$ and usual chemicals were purchased from Sigma. Phosphate buffered saline 10X (PBS 10X) was prepared as follows: $\mathrm{NaCl} 137 \mathrm{mmol}, \mathrm{KCl} 2.7 \mathrm{mmol}, \mathrm{Na}_{2} \mathrm{HPO}_{4} 10.0 \mathrm{mmol}$, $\mathrm{KH}_{2} \mathrm{PO}_{4} 1.76 \mathrm{mmol}$, sterile water qs. $100 \mathrm{~mL}$. PBS $1 \mathrm{X}$ was prepared by dilution of PBS $10 \mathrm{X}$ in sterile water. Isoflurane was supplied by Shenzhen RWD life Science Co.

\subsection{Animals.}

Specific pathogen free (SPF) C57 BL/6J mice, weighting at 20-25 g (8 weeks) were purchased from the Guangdong Medical Experimental Animal Center. 5XFAD mice (strain name: B6.Cg$\operatorname{Tg}($ APPSwFILon,PSEN1*M146L*L286V)6799Vas/Mmjax), with genetic background C57BL/6 x SJL, were purchased from the Jackson Laboratory (Stock\# 34848-JAX|5XFAD, Bar Harbor, ME, USA) and propagated in the College of Life Sciences and Oceanography in Shenzhen University. Their offsprings were assessed by PCR detection (Mei5 Biotechnology, China) of the AD pathogenic genes. Their non-transgenic littermates were screened out as healthy controls. Animals were separated in groups containing males and females in a 50/50 ratio. They were housed in standard laboratory conditions: air-conditioned room, temperature $20-25^{\circ} \mathrm{C}, 12 \mathrm{~h}$ light/dark illumination cycle, free access to food and water. Drinking water was distilled water 
obtained from a Millipore Direct-Q 5 UV water purification system (Millipore SAS, France) and food was purchased from the Guangdong Medical Experimental Animal Center. Before icv and intra-hippocampal injections of $\mathrm{Cu}-\mathrm{A} \beta$, mice were anesthetized with isoflurane, using a $\mathrm{R} 500$ Series Compact Small Animal Anesthesia Machine (Shenzhen RWD Life Science Co.) according to the supplier instructions. Mice were killed by cervical dislocation after anesthesia with isoflurane. All animal experiments were conducted in accordance with ethical animal research standards of the Chinese Council on Animal Care, and approved by the Animal Ethical and Welfare Committee of Shenzhen University (permit number: AEWC-20140615-002). All efforts were made to minimize animal suffering.

\subsection{Experimental methods for the icv-CuA $\beta$ and hippo-CuA $\beta$ models.}

\subsubsection{Preparation of the $\mathrm{Cu}-\mathrm{A} \boldsymbol{\beta}_{1-42}$ solution}

Preparation of the $A \beta_{1-42}$ solution. Human $\mathrm{A} \beta_{1-42}$ monomer powder obtained after HFIP treatment $(0.1 \mu$ mole measured by BCA titration) was dissolved in DMSO $(50 \mu \mathrm{L})$. This mother solution was then diluted by addition of $200 \mu \mathrm{L}$ of deionized water. The final solution ( $400 \mu \mathrm{M}$ measured by $\mathrm{BCA}$ assay, $\mathrm{H}_{2} \mathrm{O} / \mathrm{DMSO}=80 / 20$, v/v) was stirred using a vortex (1800 rpm, 1 minute) and sonicated for 1 minute. This limpid solution was aliquoted in seven parts of $30 \mu \mathrm{L}$ each, stored at $-20{ }^{\circ} \mathrm{C}$ away from light, covered with an aluminum foil (Solution A).

Preparation of the $\mathrm{CuCl}_{2}$ solution. A $40 \mathrm{mM}$ stock solution of copper(II) chloride was prepared by dissolution of $\mathrm{CuCl}_{2}(2.70 \mathrm{mg})$ in DMSO $(500 \mu \mathrm{L})$. This stock solution was diluted 20 times in DMSO, to provide a $2 \mathrm{mM}$ solution (Solution B).

Preparation of the $\mathrm{Cu}-\mathrm{A} \beta_{1-42}$ solution. The copper-A $\beta_{1-42}$ complex was prepared in a $1 / 1$ metal/peptide ratio, as follows. An aliquot of the human $A \beta_{1-42}$ (above Solution A, $30 \mu \mathrm{L}$ ) was kept at room temperature for $30 \mathrm{~min}$. One mole equivalent of $\mathrm{CuCl}_{2}$ in $\mathrm{DMSO}$ (Solution $\mathrm{B}, 6 \mu \mathrm{L}$ ), was then added in the flask containing the solution A, the mixture was vortexed for $30 \mathrm{sec}$, and then allowed to stand at $37{ }^{\circ} \mathrm{C}$ for $15 \mathrm{~min}$. Then, $\mathrm{H}_{2} \mathrm{O}(18 \mu \mathrm{L})$ was added and vortexed, followed by addition of PBS $10 \mathrm{X}(6 \mu \mathrm{L})$, then vortexed for $30 \mathrm{sec}$. The solution was kept at $37^{\circ} \mathrm{C}$ for 15 min. It was again vortexed for $30 \mathrm{sec}$ before each injection in the mouse brains. The absence of precipitate was carefully checked before each injection. The final ratio $\mathrm{H}_{2} \mathrm{O} / \mathrm{DMSO}$ was $80 / 20$, v/v. This solution (Solution C) was freshly prepared each day, before the intracerebroventricular (icv-CuA $\beta$ model) or intrahippocampal (hippo-CuA $\beta$ model) injections.

\subsubsection{Injection of $\mathrm{Cu}-\mathrm{A \beta}_{1-42}$ in mouse brain ventricle. (icv-CuAß model).}


484

485

486

487

488

489

490

491

492

493

494

495

496

497

498

499

500

501

502

503

504

505

506

507

508

509

510

511

512

513

514

515

Injections were performed using the protocol adapted from Reference 5. The 35 mice were randomly assigned to one of the five following groups ( 7 mice in each group): control mice, mice which received a single bilateral intracerebroventricular injection of $\mathrm{Cu}-\mathrm{A} \beta_{1-42}$ complex (icv$\mathrm{CuA} \beta$ group), icv-CuA $\beta$ mice treated with TDMQ20 (TDMQ20 group), icv-CuA $\beta$ mice treated with TDMQ22 (TDMQ22 group), and icv-CuA $\beta$ mice treated with clioquinol (CQ group). The intracerebroventricular injections were made at 2 months (mo) of age, with PBS 1X containing 20 vol\% of DMSO for the control group, or $\mathrm{Cu}-\mathrm{A} \beta_{1-42}$ Solution $\mathrm{C}$, the four other groups. The coordinates of the injection sites in each lateral ventricle were: $(\mathrm{AP})=-0.5 \mathrm{~mm}$ from bregma; $(\mathrm{L})=+/-1 \mathrm{~mm}$ from bregma; and $(\mathrm{D})=-2.5 \mathrm{~mm}$ from skull. The skull was drilled, and an injector (27 G, $35 \mathrm{~mm}$ ) was guided successively into the two lateral ventricles, using a mouse brain localization injector (RWD, Shenzhen, China). Then, $2.5 \mu \mathrm{L}$ of solution $\mathrm{C}$ or PBS 1X containing $20 \%$ DMSO was injected directly into each of the two lateral ventricles (total volume of injection $=5 \mu \mathrm{L}$ per mouse), using a $5 \mu \mathrm{L}$ syringe mounted on an automated pump. In each ventricle, the solution was delivered at a rate of $0.5 \mu \mathrm{L} / \mathrm{min}$. After each injection, the injector was let in place for $5 \mathrm{~min}$ to avoid flow back of the solution.

\subsubsection{Injection of $C u-A \beta_{1-42}$ in mouse hippocampus (hippo-CuAß model).}

The mice were randomly assigned to one of the four following groups ( 7 mice in each group): control mice, mice which received a single bilateral intrahippocampal injection of $\mathrm{Cu}-\mathrm{A} \beta_{1-42}$ complex (hippo-CuA $\beta$ ), hippo-CuA $\beta$ mice treated with TDMQ20, hippo-CuA $\beta$ mice treated with clioquinol (CQ group). The injections in the two CA3 hippocampus regions were made at 2 months of age, with PBS $1 \mathrm{X}$ containing $20 \mathrm{vol} \%$ of DMSO for the control group, or $\mathrm{Cu}-\mathrm{A} \beta_{1-42}$ Solution $\mathrm{C}$, for the three other groups. The coordinates of the injection sites were: $(\mathrm{AP})=-2.18$ $\mathrm{mm}$ from bregma; (L) = +/ $2.3 \mathrm{~mm}$ from bregma; and $(\mathrm{D})=-2.15 \mathrm{~mm}$ from skull. The skull was drilled, and an injector $(27 \mathrm{G}, 35 \mathrm{~mm})$ was guided successively into the bilateral CA3 hippocampal regions. The delivery of the $\mathrm{Cu}-\mathrm{A} \beta_{1-42}$ (solution $\mathrm{C}, 2 \times 2.5 \mu \mathrm{L}$ of the $\mathrm{Cu}-\mathrm{A} \beta_{1-42}$ solution C, or the PBS $1 \mathrm{X} / \mathrm{DMSO}, 80 / 20$, v/v into the bilateral hippocampal CA3 region was carried out in the same way than icv injections, except that the flow rate was $0.25 \mu \mathrm{L} / \mathrm{min}$ (compared to $0.5 \mu \mathrm{L} / \mathrm{min}$ for cerebroventricular space, in order to avoid damage to the smaller hippocampus).

\subsubsection{Preparation of drug solutions, drug dose, and treatment.}

Mother solutions of TDMQ20, TDMQ22 were prepared by dissolving $25 \mathrm{mg}$ of each drug in 10 $\mathrm{mL}$ of $\mathrm{NaCl} 0.9 \%(\mathrm{w} / \mathrm{v})$ solution. Clioquinol $(25 \mathrm{mg})$ was dissolved in $10 \mathrm{~mL}$ of DMSO. $100 \mu \mathrm{L}$ 
516 of such drug solutions contained $0.25 \mathrm{mg}$ of drug. While the injections of $\mathrm{Cu}-\mathrm{A} \beta_{1-42}$ into ventricles

517 or hippocampus were carried out on D0, the mice were treated intragastrically 8 times (at D4, D6, 518 D9, D11, D13, D16, D18, and D20) as follows: $\mathrm{NaCl} 0.9 \%(\mathrm{w} / \mathrm{v})$ in distilled water $(100 \mu \mathrm{L})$ for 519 the control groups, the icv-CuA $\beta$ group, and the hippo-CuA $\beta$ group, TDMQ20 in $\mathrm{NaCl} 0.9 \%$ $520(100 \mu \mathrm{L})$ for the TDMQ20 groups, TDMQ22 in $\mathrm{NaCl} 0.9 \%(100 \mu \mathrm{L})$ for the TDMQ22 groups, and CQ in DMSO $(100 \mu \mathrm{L})$ for the CQ group. Each drug dose was therefore $10 \mathrm{mg} \mathrm{kg}^{-1}$ for TDMQ20, TDMQ22, and CQ. Mice were individually weighted on the day of the intracerebral injection of $\mathrm{Cu}-\mathrm{A} \beta$ ( 2 months of age) for the icv- $\mathrm{CuA} \beta$ - and hippo-CuA $\beta$ models, and the exact volume of drug solution for each mouse was calculated accordingly. For 5XFAD mice, animals were weighted at the age of two months (beginning of treatment) and the volumes of drug solutions were calculated accordingly.

\subsection{Experimental methods for the 5XFAD transgenic model.}

At the age of 2 months, mice were weighted and randomly assigned to one of the following groups: untreated 5XFAD mice, 5XFAD mice treated with TDMQ20, 5XFAD mice treated with $\mathrm{CQ}$, compared to wild type C57BL/6 x SJL mice. The drugs were dissolved in $0.9 \% \mathrm{NaCl}$ (TDMQ20) or DMSO (CQ), and were delivered to the stomach of mice once every two days during the three following months (45 treatments, total drug dose: $450 \mathrm{mg} \mathrm{kg}^{-1}$ ). Each drug dose consisted of $10 \mathrm{mg} \mathrm{kg}^{-1}$ of mouse weight contained in $100 \mu \mathrm{L}$ of solvent. All control and untreated mice received oral gavage with aqueous $\mathrm{NaCl} 0.9 \%$ instead of drug. The behavioral tests were performed at the end of the treatment, between 5.0 and 5.5 months of age.

\subsection{Behavioral tests.}

\subsubsection{Novel object recognition test (NOR).}

540 The test was carried out as previously reported. ${ }^{28}$ Mice were tested in an uncovered square box $541(40 \mathrm{~cm} \times 40 \mathrm{~cm} \times 40 \mathrm{~cm})$. This open arena is divided into 25 equal squares. At D22 after the injection of $\mathrm{Cu}-\mathrm{A} \beta$ in the ventricles or hippocampus (two days after the last administration of drug), each mouse was placed for $5 \mathrm{~min}$ in the empty arena of the box placed in the test room equipped with daylight lamp, in order to habituate it to the environment and to the apparatus (habituation phase). At D23, the home cages were left for acclimation in the test room for one

546 hour prior to the beginning of the test session (acclimation phase). Each mouse was then placed for $5 \mathrm{~min}$ in the arena containing two identical objects ( $\mathrm{X}$ and $\left.\mathrm{X}^{\prime}\right)$ (acquisition phase). After a 90 
min retention interval in its home cage, the mouse was placed back into the arena and exposed to one of the familiar objects (X) and to a novel object (Y), for a short-term (90 min) recognition memory test. The mouse was initially placed in the apparatus facing the wall and allowed to explore the objects for $5 \mathrm{~min}$. When the mouse's nose pointed or touched an object within $1 \mathrm{~cm}$, it was recorded as an exploration behavior. The number of times the mouse explored one of the two objects was recorded. At D24, each mouse was similarly placed into the arena for 5 min, in the presence of a different pair of dissimilar objects (a familiar and a novel one; $\mathrm{X}$ and $\mathrm{Z}$, respectively), for a long-term ( 1 day) recognition memory test. The recognition index, defined as the ratio of the number of times the novel object was explored to the number of times both objects were explored, was used to measure the memory function. So, the recognition indexes were calculated as $\mathrm{n}_{\mathrm{Y}} / \mathrm{n}_{(\mathrm{X}+\mathrm{Y})}$ and $\mathrm{n}_{\mathrm{Z}} / \mathrm{n}_{(\mathrm{X}+\mathrm{Z})}$ for the short-term memory and long-term memory, respectively, where $\mathrm{n}_{\mathrm{X}}, \mathrm{n}_{\mathrm{Y}}, \mathrm{n}_{\mathrm{Z}}$ stand for the number of explorations of objects $\mathrm{X}, \mathrm{Y}$ or $\mathrm{Z}$, respectively. Between trials, the arena was cleaned with $75 \%$ ethanol to eliminate animal clues, and then with water. For the 5XFAD mice, the schedule of the test was the same as described above, and the test begun at $5.3 \pm 0.1$ months of age.

\subsubsection{Elevated plus maze test (EPM).}

The elevated plus maze test was carried out using the protocol adapted from References 41 and 42. The experiment was started at D26 from intracerebral injection. The home cages were left for acclimation in the test room equipped with daylight lamp, for one hour prior to the beginning of the test session. The elevated plus maze apparatus consisted of four arms of $30 \mathrm{~cm}$ length $\times 5 \mathrm{~cm}$ width, two of them with $30 \mathrm{~cm}$ high walls, elevated at $60 \mathrm{~cm}$ above the floor. The mouse was initially placed in the center of the maze, facing an open arm and allowed to explore the maze for $5 \mathrm{~min}$. The number of times the mouse entered the open and closed arms was recorded, as well as the time spent in the open and closed arms. If the mouse fell off an open arm, the trial was stopped and excluded from the analysis. For 5XFAD mice, the test was carried out at $5.4 \pm 0.1 \mathrm{mo}$. of age. Between trials, the arena was cleaned with $75 \%$ ethanol to eliminate animal clues, and then with water.

\subsubsection{Open field test (OFT).}

The test was carried out at D26 after intracerebral injection, using the protocol adapted from References 43 and 44. The home cages were left for acclimation in the test room equipped with daylight lamp, for one hour prior to the beginning of the test session. The test field consisted of an empty square box of $100 \times 100 \times 30 \mathrm{~cm}$, with 25 square grids on the floor. Each mouse was 
initially put at the center of the field, and allowed to explore it for $5 \mathrm{~min}$. A digital camera was placed $2 \mathrm{~m}$ above and its field of view covered the entire experimental field. The number of rearings, crossings of the floor grid, and walking distances of mice were recorded. For 5XFAD mice, the test was carried out at $5.4 \pm 0.1$ months of age. 3.5.4. Y-maze test (YMT).

The Y-maze test was carried out using the protocol adapted from Reference 45. The home cages were left for acclimation in the test room equipped with daylight lamp, for one hour prior to the beginning of the test session. Spontaneous alternation behavior test has been performed in a symmetrical black plexiglas Y-maze with three arms $(30 \mathrm{~cm}$ long $\times 10 \mathrm{~cm}$ wide $\times 30 \mathrm{~cm}$ high $)$ at $120^{\circ}$ angles. For $5 \mathrm{XFAD}$ mice, the test was carried out at $5.5 \pm 0.1$ months of age. The mice were initially placed in the center of the maze and allowed to explore the maze for $5 \mathrm{~min}$. A successful alternation was defined as any three consecutive choices of three different arms without reexploration of a previously visited arm. Alternation rate (\%) was calculated as follows: number of triads containing entries into all three arms/maximum possible alternations (the total number of arms entered -2$) \times 100$.

\subsection{Biochemical analyses.}

\subsubsection{Titration of malondialdehyde (MDA).}

598 After all behavioral experiments have been performed, all the mice had a rest for one day and then were sacrificed. The concentration of malondialdehyde (MDA) was determined in cortex of C57 $\mathrm{BL} / 6 \mathrm{~J}$ control mice, and icv-CuA $\beta$ mice $\pm \mathrm{TDMQ} 20$ or $\mathrm{CQ}$, using the thiobarbituric assay according to the manufacturer's instructions (Nanjing Jiancheng Bioengineering Institute, China). The cortex (ca. $100 \mathrm{mg}$ was homogenized in $1 \mathrm{~mL}$ of phosphate buffer (pH 7.4, $10 \mathrm{mM})$. After centrifugation for $10 \mathrm{~min}(3,000 \mathrm{~g})$, the MDA content in the supernatant was measured by UVvisible spectrometry at $532 \mathrm{~nm}$. The levels of MDA are indicated as nmol/mg protein.

\subsubsection{Titration of AST, ALT, creatinine and urea.}

After all behavioral experiments have been performed, all 5XFAD mice had a rest for one day and then were sacrificed (5.6 months of age). The concentration of AST, ALT, creatinine and urea in the serum were measured using the automatic biochemical analyzer iMagic-M7, the assay kits and the software of the iCubio company (Shenzhen, China).

\subsection{Preliminary toxicologic experiments}




\section{3.7.1. Single dose (acute toxicity).}

613 TDMQ20 and CQ were administered by gavage or by intraperitoneal injection, at 150 or $200 \mathrm{mg}$ $614 \mathrm{~kg}^{-1}$, to $\mathrm{C} 57 \mathrm{BL} / 6 \mathrm{~J}$ mice (groups of 5-11 mice each), using $25 \mathrm{mg} \mathrm{mL}^{-1}$ solutions in $0.9 \% \mathrm{NaCl}$ 615 (for TDMQ20) or in DMSO (for CQ). Mice were observed for 16 days after the administration.

\section{3.7.2. Multiple doses.}

$617 \mathrm{C} 57 \mathrm{BL} / 6 \mathrm{~J}$ mice received TDMQ20 $\left(25 \mathrm{mg} \mathrm{mL}^{-1}\right.$ solution in $\left.0.9 \% \mathrm{NaCl}\right)$ by intragastric 618 administration at $100 \mathrm{mg} \mathrm{kg}^{-1}$ per day during 9 days (10 mice), or at $60 \mathrm{mg} \mathrm{kg}^{-1}$ per day, three 619 times per week during two weeks (12 mice). Mice were weighted each day.

620

\subsection{Statistical analysis.}

622 Figures 2-6 and Figure S1 are presented as univariate scatterplots of all the individual data points obtained, with mean and SEM superimposed. Data with multiple independent experiments were analyzed by one-way ANOVA, followed by multiple comparisons LSD test when the ANOVA was significant $(p<0.05) . p$-levels $<0.05,0.01$ and $<0.001$ were noted $*$, ** and ***, of the treatment was entered as a within-subjects (independent) factor. The F-statistic, degrees of freedom, $p$-value and the magnitude of the difference were calculated. All statistical calculations are provided as Supporting Information (SI).

\section{ASSOCIATED CONTENT}

632 The Supporting Information is available free of charge at https://pubs.acs.org/doi/...

633 The Supporting Information contain:

634 - Figure S1 (duplicate of Figure 2),

635 - Raw data and statistical analysis of results reported in Figures 2-6,

636 - ADME-toxicological data of TDMQ20.

637

\section{AUTHOR INFORMATION}

\section{Corresponding Authors}

640 Anne Robert - Laboratoire de Chimie de Coordination du CNRS (LCC-CNRS), 205 route de 641 Narbonne, 31077 Toulouse, cedex 4, France; orcid.org/0000-0002-9092-6776; anne.robert@1cc642 toulouse.fr 
643 Qiong Liu - College of Life Sciences \& Oceanography, Shenzhen University, 1066 Xueyuan

644 boulevard, Nanshan District, Shenzhen 518055, P. R. China; orcid.org/0000-0002-6431-3650;

645 liuqiong@szu.edu.cn

646 Bernard Meunier - Laboratoire de Chimie de Coordination du CNRS (LCC-CNRS), 205 route de

647 Narbonne, 31077 Toulouse, cedex 4, France, and School of Chemical Engineering and Light

648 Industry, Guangdong University of Technology (GDUT), Higher Education Mega Center, 100

649 Waihuan Xi road, Panyu District, Guangzhou 510006, P. R. China; orcid.org/0000-0003-2200-

650 7142; bmeunier@1cc-toulouse.fr

651

\section{Other Authors}

653 Jie Zhao - College of Life Sciences \& Oceanography, Shenzhen University, 1066 Xueyuan 654 boulevard, Nanshan District, Shenzhen 518055, P. R. China, and College of Optoelectronic 655 Engineering, Shenzhen University, Shenzhen 518060, China; orcid.org/0000-0002-7878-9801.

656 Qihui Shi - College of Life Sciences \& Oceanography, Shenzhen University, 1066 Xueyuan 657 boulevard, Nanshan District, Shenzhen 518055, P. R. China; orcid.org/0000-0002-7172-7368.

658 Hongda Tian - School of Chemical Engineering and Light Industry, Guangdong University of 659 Technology (GDUT), Higher Education Mega Center, 100 Waihuan Xi road, Panyu District, 660 Guangzhou 510006, P. R. China.

661 Youzhi Li - School of Chemical Engineering and Light Industry, Guangdong University of 662 Technology (GDUT), Higher Education Mega Center, 100 Waihuan Xi road, Panyu District, 663 Guangzhou 510006, P. R. China.

664 Yan Liu - School of Chemical Engineering and Light Industry, Guangdong University of 665 Technology (GDUT), Higher Education Mega Center, 100 Waihuan Xi road, Panyu District, 666 Guangzhou 510006, P. R. China; orcid.org/0000-0002-3864-1992.

667 Zhen $\mathrm{Xu}$ - Shenzhen Institutes of Advanced Technology, Chinese Academy of Sciences, 668 Shenzhen 518055, China.

669

670 Author Contributions

671 B. M., Q. L. and A. R. designed research; H. T., Y. Li and Y. Liu performed chelator synthesis; 672 J. Z. and Q. S. performed biological assays and animal experiments; B. M., Q. L., J. Z. and A. R. 673 analyzed the data; B. M., A. R. and Q. L. wrote the manuscript. 
676 This work was financially supported by the Guangdong Provincial Key S\&T Program 677 (2018B030336001), NSFC (grants 21977019 and 21877081), the Guangdong Province (Program 678 for Innovative Research Teams and Leading Talents Introduction, grant 2050205), the Open 679 Project of Guangdong Provincial Key Laboratory of New Drug Screening (No.GDKLNDS680 2018OF004), and the University of Technology of the Guangdong (GDUT) (grant 220418037) of 681 the P. R. China, and by the CNRS, France.

682

\section{Conflict of Interest}

684 Y. L., A. R. and B. M. are co-authors of a pending patent on use of TDMQ chelators as a 685 therapeutic for Alzheimer's disease (WO 2017/202360 A1). None of the authors have a financial 686 interest in pharmaceutical companies.

687

\section{REFERENCES}

1. WHO. Data on AD. (2019). Retrieved from https://www.who.int/news-room/factsheets/detail/dementia. Accessed September 8, 2020.

2. Meunier, B. (2016). Age and Alzheimer's disease. Nutrients, 8, 372.

3. Wang, X., Sun, G., Feng, T., Zhang, J., Huang, X., Wang, T., Xie, Z., Chu, X., Yang, J., Wang, H., Chang, S., Gong, Y., Ruan, L., Zhang, G., Yan, S., Lian, W., Du, C., Yang, D., Zhang, Q., Lin, F., Liu, J., Zhang, H., Ge, C., Xiao, S., Ding, J., Geng, M. (2019). Sodium oligomannate therapeutically remodels gut microbiota and suppress gut bacterial amino acids-shaped neuroinflammation to inhibit Alzheimer's disease progression. Cell Res., 29, 787-803.

4. Cummings, J. L., Morstorf, T., Zhong, K. (2014). Alzheimer's disease drug-development pipeline: few candidates, frequent failures. Alzheimer's Res. Ther., 6, 37-43.

5. Ceccom, J., Coslédan, F., Halley, H., Francès, B., Lassalle, J.-M., Meunier, B. (2012). Copper chelator induced efficient episodic memory recovery in a non-transgenic mouse model. Plos One, 7, e43105.

6. Selkoe, D. J., Hardy, J. (2016). The amyloid hypothesis of Alzheimer's disease at 25 years. EMBO Mol. Med., 8, 595-608. 
706

707

708

709

710

711

712

713

714

715

716

717

718

719

720

721

722

723

724

725

726

727

728

729

730

731

732

733

734

735

736

7. Tomiyama, T., Matsuyama, S., Iso, H., Umeda, T., Takuma, H., Ohnishi, K., Ishibashi, K., Teraoka, R., Sakama, N., Yamashita, T., Nishitsuji, K., Ito, K., Shimada, H., Lambert, M. P., Klein, W. L., Mori, H. (2010). A mouse model of amyloid $\beta$ oligomers: Their contribution to synaptic alteration, abnormal tau phosphorylation, glial activation and neuronal loss in vivo. J. Neurosci, 30, 4845-4856.

8. Zhang, F., Gannon, M., Chen, Y., Yan, S., Zhang, S., Feng, W., Tao, J., Sha, B., Liu, Z., Saito, T., Saido, T., Keene, C. D., Jiao, K., Roberson, E. D., Xu, H., Wang, Q. (2020). $\beta$ amyloid redirects norepinephrine signaling to activate the pathogenic GSK3 $3 /$ tau cascade. Sci. Transl. Med., 12, eaay6931.

9. Nguyen, M., Robert, A., Sournia-Saquet, A., Vendier, L., Meunier, B. (2014). Characterization of new specific copper chelators as potential drugs for the treatment of Alzheimer's disease. Chem. Eur. J., 20, 6771-6785.

10. Nguyen, M., Bijani, C., Martins, N., Meunier, B., Robert, A. (2015). Transfer of copper from an amyloid to a natural copper-carrier peptide with a specific mediating ligand. Chem. Eur. J., 21, 17085-17090.

11. Liu, Y., Nguyen, M., Robert, A., Meunier, B. (2019). Metals ions in Alzheimer's disease: a key role or not? Acc. Chem. Res., 52, 2026-2035, and references therein.

12. Zhang, W., Huang, M., Bijani, C., Liu, Y., Robert, A., Meunier, B. (2018). Synthesis and characterization of copper specific tetradentate ligands as potential treatment for Alzheimer's disease. C. R. Chimie, 21, 475-483.

13. Zhang, W., Huang, D., Huang, M., Huang, J., Wang, D., Liu, X., Nguyen, M., Vendier, L., Mazères , S., Robert, A., Liu, Y., Meunier, B. (2018). Preparation of new tetradentate copper chelators as potential anti-Alzheimer agents. ChemMedChem, 13, 684-704.

14. Huang, J., Nguyen, M., Liu, Y., Robert, A., Meunier, B. (2019). The TDMQ regulators of copper homeostasis do not disturb $\mathrm{Cu}, \mathrm{Zn}-\mathrm{SOD}$ and tyrosinase activity, nor the Co(III) cofactor vitamin B12. Eur. J. Inorg. Chem., 1384-1388.

15. Li, Y., Nguyen, M., Baudoin, M., Vendier, L., Liu, Y., Robert, A., Meunier, B. (2019). Why is tetradentate coordination essential for potential copper homeostasis regulators in Alzheimer's disease? Eur. J. Inorg. Chem., 4712-4718.

16. Adlard, P. A., Bush, A. I. (2018). Metal and Alzheimer's disease: How far have we come in the clinic? J. Alz. Dis., 62, 1369-1379. 
17. Prana Biotechnology announces preliminary results of Phase 2 IMAGINE trial of PBT2 in Alzheimer's disease. (2014). Retrieved from https://www.prnewswire.com/news$\underline{\text { releases/prana-biotechnology-announces-preliminary-results-of-phase-2-imagine-trial-of- }}$ pbt2-in-alzheimers-disease-253173581.html. Accessed September 8, 2020.

18. Nguyen, M., Rechignat, L., Robert, A., Meunier, B. (2015). The necessity of having a tetradentate ligand to extract copper(II) ions from amyloids. ChemistryOpen, 4, 27-31.

19. Nguyen, M., Vendier, L., Stigliani, J. -L., Meunier, B., Robert, A. (2017). Structures of copper and zinc complexes of PBT2, a chelating agent evaluated as potential drug for neurodegenerative diseases. Eur. J. Inorg. Chem., 600-608.

20. Zhang, W., Liu, Y., Hureau, C., Robert, A., Meunier, B. (2018). N4-Tetradentate chelators efficiently regulate copper homeostasis and prevent ROS production induced by copperamyloid, even in the presence of an excess of zinc. Chem. Eur. J., 24, 7825-7829.

21. West, M. J. (1993). Regionally specific loss of neurons in aging human hippocampus. Neurobiol. Aging, 14, 287-293.

22. Mu, Y., Gage, F. H. (2011). Adult hippocampal neurogenesis and its role in Alzheimer's disease. Molec. Neurodegener., 6, 85.

23. Halliday, G. (2017). Pathology and hippocampal atrophy in Alzheimer's disease. Lancet Neurol., 16, 862-864.

24. Oakley, H., Cole, S. L., Logan, S., Maus, E., Shao, P., Craft, J., Guillozet-Bongaarts, A., Ohno, M., Disterhoft, J., Van Eldik, L., Berry R., Vassar, R. (2006). Intraneuronal $\beta$-amyloid aggregates, neurodegeneration, and neuron loss in transgenic mice with five familial Alzheimer's disease mutations: Potential factors in amyloid plaque formation, J. Neurosci., 26, 10129-10140.

25. Jawhar, S., Trawicka, A., Jenneckens, C., Bayer, T. A., Wirths, O. (2012). Motor deficits, neuron loss, and reduced anxiety coinciding with axonal degeneration and intraneuronal $\mathrm{A} \beta$ aggregation in the 5XFAD mouse model of Alzheimer's disease. Neurobiol. Aging, 33, 196.e29-196.e40.

26. Schneider, F., Baldauf, K., Wetzel, W., Reymann, K. G. (2014). Behavioral and EEC changes in male 5xFAD mice. Physiol. Behav., 135, 25-33.

27. Urano, T., Tohda, C. (2010). Icariin improves memory impairment in Alzheimer's disease model mice (5xFAD) and attenuates amyloid $\beta$-induced neurite atrophy. Phytother. Res., 24 , 1658-1663. 
28. Morroni, F., Sita, G., Tarozzi, A., Rimondini, R., Hrelia, P. (2016). Early effects of A $\beta_{1-42}$ oligomers injection in mice: involvement of PI3K/Akt/GSK3 and MAPK/ERK1/2 pathways. Behav. Brain Res., 314, 106-115.

29. Grayson, B., Leger, M., Piercy, C., Adamson, L., Harte, M., Neill, J. C. (2015). Assessment of disease-related cognitive impairments using the novel object recognition (NOR) task in rodents. Behav. Brain Res., 285, 176-193.

30. Ardestani, P. M., Evans, A. K., Yi, B., Nguyen, T., Coutellier, L., Shamloo, M. (2017). Modulation of neuroinflammation and pathology in the 5XFAD mouse model of Alzheimer's disease using a biased and selective beta-1 adrenergic receptor partial agonist. Neuropharmacol., 116, 371-386.

31. Kraeuter, A. K., Guest, P. C., Sarnyai, Z. (2019). The Y-maze for assessment of spatial working and reference memory in mice. Methods Mol. Biol., 1916, 105-111.

32. Conrad, C. D., Galea, L. A. M., Kuroda, Y., McEwen, B. S. (1996). Chronic stress impairs rat spatial memory on the Y maze, and this effect is blocked by tianeptine pretreatment. Behav. Neurosci., 110, 1321-1334.

33. Ohno, M., Sametsky, E. A., Younkin, L. A., Oakley, H., Younkin, S. G., Citron, M., Vassar, R., Disterhoft, J. F. (2004). BACE1 deficiency rescues memory deficits and cholinergic dysfunction in a mouse model of Alzheimer's disease. Neuron, 41, 27-33.

34. File, S. E. (2001). Factors controlling measures of anxiety and responses to novelty in the mouse. Behav. Brain Res., 125, 151-157.

35. Walf, A. A., Frye, C. A. (2007). The use of the elevated plus maze as an assay of anxietyrelated behavior in rodents. Nat. Protoc., 2, 322-328.

36. Webster, S. J., Bachstetter, A. D., Van Eldik, L. J. (2013). Comprehensive behavioral characterization of an APP/PS-1 double knock-in mouse model of Alzheimer's disease. Alzheimer Res. Ther., 5, 28.

37. Tsikas, D. (2017). Assessment of lipid peroxidation by measuring malondialdehyde (MDA) and relatives in biological samples: analytical and biological challenges. Anal. Biochem., 524, 13-30.

38. Pajouhesh, H., Lenz, G. R. (2005). Medicinal chemical properties of successful central nervous system drugs. NeuroRx, 2, 541-553.

39. ChemDraw Prime software, version 19.0.0.26. 
40. Zhang, C., Wan, X., Zheng, X., Shao, X., Liu, Q., Zhang, Q., Qian, Y. (2014). Dual-functional nanoparticulates targeting amyloid plaques in the brains of Alzheimer's disease mice. Biomaterials, 35, 456-464.

41. Lister, R. G. (1987). The use of a plus-maze to measure anxiety in the mouse. Psychopharmacology, 92, 180-185.

42. JiaWen, W., Hong, S., ShengXiang, X., Jing, L. (2018). Depression- and anxiety-like behaviour is related to BDNF/TrkB signalling in a mouse model of psoriasis. Clin. Exp. Dermatol., 43, 254-261.

43. Garcez, M. L., Mina, F., Bellettini-Santos, T., da Luz, A. P., Schiavo, G. L., Carollo Macieski, J. M., Behenck Medeiros, E., Oliveira Marques, A., Quadros Magnus, N., Budni, J. (2018). The involvement of nlrp3 on the effects of minocycline in an ad-like pathology induced by $\beta$-amyloid oligomers administered to mice. Mol. Neurobiol., 56, 2606-2617.

44. Xie, Y., Liu, Q., Zheng, L., Wang, B., Qu, X., Ni, J., Zhang, Y., Du, X. (2018). SeMethylselenocysteine ameliorates neuropathology and cognitive deficits by attenuating oxidative stress and metal dyshomeostasis in Alzheimer model mice. Mol. Nutr. Food Res., 62, e1800107.

45. Takagane, K., Nojima, J., Mitsuhashi, H., Suo, S., Yanagihara, D., Takaiwa, F., Urano, Y., Noguchi, N., Ishiura, S. (2015). A $\beta$ induces oxidative stress in senescence-accelerated (SAMP8) mice. Biosc. Biotech. Biochem., 79, 912-918. 
Revised ms ID cn-2020-00621j to ACS Chemical Neuroscience, December 3, 2020

\section{Scheme for Table of Contents only}

822

823

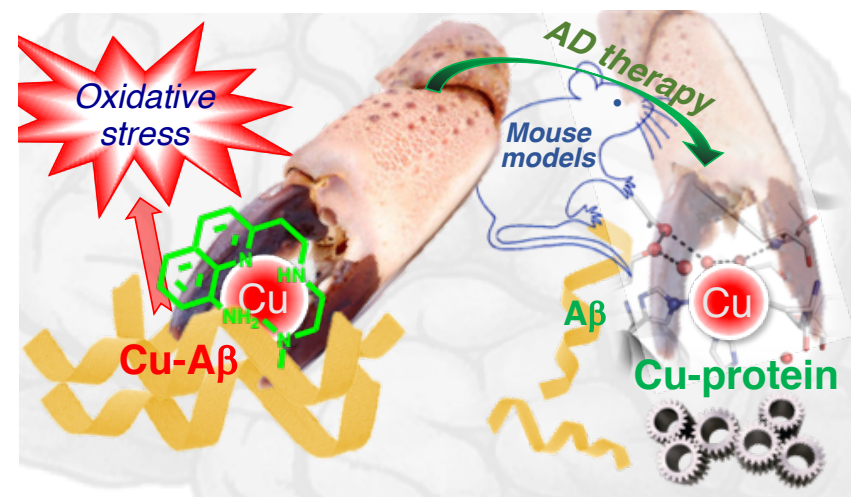

